\title{
India-Pakistan: Emerging Trends in Strategic Dynamics
}

\author{
Zulfqar Khan
}

\begin{abstract}
Since the partition of British India, the dynamics of South Asia has been based on divergent threat perceptions between India and Pakistan, which has further undermined their bilateral relations due to increased mistrust, economic, military, and diplomatic asymmetries. In spite of India's rise, it is still entangled with multiple disputes with its nuclear peers, including Pakistan and China. Particularly, it has complicated India-Pakistan bilateral relationship, created a 'stability-instability paradox,' and consequently widened the expanse of military asymmetry, which is motivating them to crafting of more offensive conventional and nuclear posturing. This mutual animosity has generated a 'fear of each other' that had clouded their mutual perceptions, and impacted their behavior. In essence, it has locked them into a perpetual cycle of 'security dilemma.' On the other hand, notwithstanding Pakistan's internal security issues, its geostrategic position would continue to endow it to play a pivotal role together with the regional, Western and Far Eastern countries, including the United State (U.S.) and China. Pakistan is a tough and resilient country that possesses sufficient conventional and nuclear forces to make it impregnable for its rivals to surmount. The 21 st century is expected to witness an intensification of rivalry between U.S. and China in the Asia-Pacific, and simultaneously flanked by China, India and U.S. in the Indian Ocean. In the context of foreign policy, Pakistan instead of bandwagoning would be better off to balance it in conformity with the changing dynamics of globalized world.
\end{abstract}

Key Words: India-Pakistan, China, U.S., South Asia, strategic dynamics, forces, divergent

I $\mathrm{t}$ is argued that both India and Pakistan are traversing on divergent strategic trajectories. Consequently, these trends are expected to broaden the gulf of misperceptions, security perspectives, and thereby negatively impacting the emerging strategic dynamics of the region. Nowadays, regionalism and regional security has gained more significance (Buzan and Waever, 2003; Stewart-

* Dr Zulfqar Khan (hodsns@ndu.edu.pk) is a Professor and Head of the Department of Strategic Studies, National Defense University, Islamabad. He possesses extensive experience in the field of research and analysis, including relating to nuclear, defence, security, conflict, and diplomatic issues, while serving in different institutions and universities. He is a former Senior Analyst, Ministry of Defence, Pakistan. The views expressed in this piece are those of the author and should not be taken to represent the views of NDU.

The Korean J ournal of International Studies Vol.13-3 (December 2015), 577-607.

http://dx.doi.org/10.14731/kjis.2015.12.13.3.577

(c) 2015 The Korean Association of International Studies 
Ingersoll and Frazier). In the realm of security and power, since the times of Thucydides, scholars have discussed correlation between the two (Strassler 1976; Rex Warner). However, the contemporary realist schools of thought that cater for different aspects of security, including offensive-realists that propagate the structural motivations of states to acquire power (Mearsheimer 2001); the defensive realism is aligned to Robert Art's perspective that 'most states most of the time' enjoy certain level of security (Art 1982, 14); and while 'unipolar realism' stands for accumulation of power by a state discourages aggression and thereby assists in securing stability of the system (Wohlforth 1999, 5-41). Essentially, security in Waltz's viewpoint is state's pursuit to balance against the rival power (Walt 1987). There is yet another school of thought that contradicts the notion of balancing, and maintains that it is the national interests of the states that primarily molds its behavior (Schweller 1994, 72-107; Schroeder 1994, 117-118). The balancing acts of states are invariably in pursuit of security that enables the states to conflicting behavior vis-à-vis each other. Waltz describing correlation between security and power writes that: 'Excessive weakness may invite an attack that greater strength would have dissuaded an adversary from launching. Excessive strength may prompt other states to increase their arms and pool their efforts against the dominant state' (Waltz 1988, 616). This in the point of view of Davide Fiammenghi is 'parabolic relationship between power and security,' which means that 'increase in a state's power represents an increase in its security,' while 'power begin to diminish the state's security, because the ongoing accumulation of capabilities causes allies to defect and opponents to mobilize,' and consequently compelling the state to bandwagon (Fiammenghi 2011, 128). On the other hand, Elman observes that Waltz's balancing theory seems to be in line with the power transition school of thought (Elman 1995, 185-186). In addition, since the end of the Cold War, the concept of traditional 'state-centric' security agenda has now been transformed and included 'other sectors than the military, giving equal emphasis to domestic and trans-border' and transnational threats (Buzan and Hansen 2009, 187-188).

In South Asia, both countries had inherited a huge divergent baggage of history, which was infested with political, cultural, religious and social ethos since the partition of the British India in 1947. The first Prime Minister of India, Jawaharlal Nehru on June 3,1947, claimed that the 'proposal to allow certain parts to secede if they so will is painful for any of us to contemplate.' Expressed optimism that: 'It may be that in this way we shall reach that united India sooner than otherwise' (Hasan 1966, 236-237). On the other hand, Mohammed Ali Jinnah stated that, both Hindus and Muslims 'neither intermarry nor inter-dine together and, indeed, they belong to two different civilizations...they have different epics, dif- 
ferent heroes, and different episodes' (Hay 1991, 229-230). Hence, IndiaPakistan's ensuing divergent foreign and security policies' goals were influenced by inherent antagonism, conflict, mistrust and perpetual rivalry to the presentday. After the overt nuclearisation of South Asia in 1998, the concept of deterrence was also influenced by the existing divergent perceptions. Their bilateral relations were heavily influenced by conflicting insights and beliefs, if the costs and benefits analyses are not judiciously taken into account. The basic factors that 'contribute to decision-makers' concepts of international relations and of other states' revolves around actors' 'beliefs about his own domestic political system' (Jervis 1984, 59; 193). Moreover, the present-day strategic dynamics of region are too in a state of transformation and realignment since the dramatic transition from Westphalian to post-Westphalian world order that emerged after the demise of the former Soviet Union in 1991 and after the catastrophe of 9/11 in 2001 (Sperling 2010, 11).

As far as the emerging strategic dynamics of the region are concerned, the foreign and security policies of India and Pakistan are directly influenced by the transition from traditional norms of state behavior governed under the ethos of the Treaty of Westphalia to post-Westphalian world; where the states are increasingly subjected to a state of interdependencies shaped by economic openness, political imperatives for welfare maximization, and democratic political principles, writes James Sperling (Ibid., 2-3). This has naturally influenced the principles of states' 'security requirements alone; security has become a structurally conditioned (impure) collective good' (Ibid., 4). This transformation at the global structural level politics has concurrently impacted India's and Pakistan's strategic outlook, national identity, instrumental preferences, and interaction preferences (Berger 2003; Banchoff 1999; Duffield 1998, Katzenstein 1996).

The paper would endeavor to delineate the regional and extra-regional multidynamics, including the geo-economic, geopolitical and technological transformations (Loo 2009) that are immensely molding the regional power dynamics associated with China and India as the stronger powers of the East and South Asian Regional Security Complex (RSC) respectively (Buzan 2011, 2). The major powers - China, India, and Pakistan still have a long list of unresolved territorial and other disputes, which are persistently bedeviling their bilateral relations, increasing 'stability-instability paradox' (Krepon 2004), and widening the gulf of military asymmetry that is further complicating the India-Pakistan nuclear deterrence postures and creating instability at the regional level (Mistry 2011, 199). The systemic instability at the regional plane is likely to negatively influence the global politics, and create more polarization between the emergent geopolitical and geo-economic power houses in 21stcentury (Buzan 2011, 2). The growing 
pace of globalization, increasing state of interdependence between the countries, transformation in military technologies - commonly termed revolution in military affairs (RMA), the development of offensive conventional weapons that are taking over the role of 'strategic deterrent,' which was earlier assigned to 'nuclear deterrent'(Fortmann 2011; Loo 2009). One, the advanced stealth conventional weapons would constitute a credible deterrent and inflict a 'tailed punishment in the event of deterrence failure' (Fortmann 2011, 317). Two, the RMA driven conventional deterrence is proving more credible due to its precision-guided warfare capabilities, and contained destruction in comparison to nuclear weapons. Three, the growing threats of asymmetric warfare can too be effectively neutralized with RMA vintage weaponry without inflicting excessive collateral destruction (Ibid.). Four, RMA weapons are expected to 'spur WMD proliferation in other states attempt to narrow the gap,' increase regional rivalries, instability, and lower a weaker country's nuclear threshold (Ibid., 315-317). Such transformations are likely to influence the powerful regional states' quest to achieve 'full spectrum dominance' with conventional deterrence against their adversaries (Ibid., 309, 317).

\section{STRATEGIC DYNAMICS}

It will be appropriate to start the argument with a question: how the strategic dynamics of a state or a region is formulated? So much has been written since realism became the predominant theory of international affairs - as it provided a straight-forward explanations for various international changes, including war, peace, imperialism, cooperation, formation of alliance systems, and other emerging phenomenon (Waltz 2004, 4-11). While the states innately struggled to enforce their domination over the other states, hence, the realist theory concludes that international politics is fundamentally a quest for power (Morgenthau 1960). It is pragmatic to focus on contemporary dynamics that directly or indirectly influence the states' quest to possess more power and security. The absence of international authority to control and regulate the prevalent 'anarchy' consequently motivates states to struggle for dominance in all political life of power and security (Gilpin 1986, 305). This gives more significance to rationality and statecentric policies while pursuing relations with other states (Keohane 1986, 164165). The concept of power is a contested term, and every country would tend to define it by keeping in view its own narrow 'interests and values' (Nye 2011, 5). Currently, the power determining index is comprised of resources - technology, enterprise, human, capital, physical; natural performance in the realm of exter- 
nal constraints, infrastructure, ideas; and how they impacted military capability and the combat proficiency (Tellis 2000). Joseph Nye writes that the frequently used terms like 'military power' or 'economic power' is a hybrid mix of 'both resources and behaviors,' including resources, raw materials, and crafting of behavior to produce preferred outcomes. The combination of 'hard and soft power resources' leads states to attain 'smart power' in the contemporary world (Nye 2011, 9-10). But, in fact, their diverse 'ideas and beliefs' had persistently influenced their policies and preferences and bilateral affairs (Lukes 2005, 97).

The most powerful regional power, India, cherished the goal of 'united India.' This was anachronistic for a less powerful entity, Pakistan. The latter remained in a perpetual state of search to strength its security thereby leading both states to compete with each other. Primarily, it was India's ideal of united India that indoctrinated the Pakistani policymakers to 'gain a position of dominant power' (Mearsheimer 2001, xi), not necessarily to challenge or to overcome the overshadowing influence of India, but to gain 'the greatest strength' as 'the greatest insurance of safety' (Ibid.) vis-à-vis India. This was a 'fear of each other' that had clouded their bilateral perceptions, which influenced their behavior and relations (Mearsheimer 2004, 55). This locked India-Pakistan into a perpetual cycle of 'security dilemma' against each other (Herz 1950, 157-180). This triggered a struggle 'to attain security from....attack (states) are driven to acquire more and more power in order to escape the impact of the power of others.' This led them to 'the vicious circle of security and power accumulation' (Ibid., 157), thereby leading both into an unending mode of competition. However, introduction of nuclear dimension to security has created a state of mutual deterrence between the adversaries (Khan and Abbasi 2013, 489-490). However, now the dynamics of global and regional politics are subtly shifting the power politics towards the redrawing of lines to contain the emerging Chinese century (Beckley 2011, 41-78). In this context, 'Geography is the most fundamental factor in the foreign policy of states because it is the most permanent,' as once Nicholas Spykman observed (Spykman 1942, XV). In fact, the modern day technological revolution has significantly 'cancelled geography' (Gray 1996), however, it has 'not conquered' it (Grygiel 2006, 15). Therefore, geography still remains a currency of great strategic consequence, maintained some eminent scholars of the last century (Kaplan 2012, 37). Apparently, Pakistan's strategic location at the mouth of Strait of Hormuz enables it to assert its geopolitical role in the region (Mackinder 1942, xviii), especially after the establishment of China-Pakistan Economic Corridor (CPEC) in April 2015. This can accord Pakistan a currency of strength to sail through the rough waters of the 21st century, where it is generally perceived in a stereo-typical negative hue in spite of suffering huge financial and human losses 
in the ongoing war against terrorism (Raja 2014; Gall 2014; "Kayani delayed" 2014).

\section{STRATEGIC STABILITY}

In the strategic realm, the concept of 'strategic stability' began to be widely used in the early years of the nuclear revolution, when in the mid-1950s U.S. policymakers deliberated the possibilities as how to use its technological capabilities in order to make its 'nuclear forces less vulnerable to surprise attack'(Gerson 2014, 14-15). The contesting concept is a dynamic phenomenon, which has raised more questions than what it had endeavored to answer (Ibid., 26, 36). This had cautioned the policymakers to dispassionately think about 'other concept in the nuclear arena, stability epitomized how the nuclear revolution required some fundamental rethinking about the nature of security and the characteristics of military forces' (Ibid., 37). In this context, Dale Walton and Colin Gray wrote that the concept of strategic stability initially was seen from the single dimension of weapons orientation instead of analyzing it holistically (Walton 2014, 85). The concept of strategic stability had revolved from the logic of stabilizing the "bipolar confrontation by ensuring that each side had the ability to strike back effectively even after an attempted disarming, first strike by its opponent' (Colby 2013, 48). They observed that, in $21^{\text {st }}$ century the strategic stability has little salience as the present-day world system is undergoing marked changes. Therefore, this concept needs to be viewed holistically with the emerging potent factors like: 'Social, economic, technological, religious/ideological' changing contours of global politics; trends of extreme violence; 'Strategic stability and strategic instability are not absolute conditions, especially in a vibrant multipolar system;' there is more propensity towards war; 'strategic stability is not inherently good - sometimes instability can allow for positive change;' that 'Strategic stability cannot reliably be increased through arms control or similar measures;' and the countries should be 'prepared to grapple with the enormously more complicated task of working to guide a rapidly emerging multipolar international system that will be confronted by the crushing pressures of technological, social, and economic change' (Ibid., 109-111). Since the 1950s, the strategic community has not agreed on a definite definition of a term strategic stability, and generally it is still seen from the lens of combination of both 'crisis stability and arms race stability' (Acton 2014, 122, 123). The most significant technological transformation of today's information age that tends to link the nuclear deterrence to other axes - 'deterrence effectiveness, cost effectiveness, bureaucratic feasibility, domestic politics, and 
alliance politics,' writes James Acton. He further outlines that; other variables like crafting of 'optimal nuclear strategy' are also important factors (Ibid., 139). Primarily, strategy connotes basic approaches to 'Sequential and Cumulative Strategies....Direct and Indirect Strategies....Deterrent and Combative strategies....Counterforce and Counter value Strategies' along with different schools of strategic thought (Collins 1973, 14-21). As argued earlier that the technological developments, economical and industrial changes are performing the role of as 'an agent of change' (Lehman II 2014, 147).

Strategic stability can vary from case-to-case basis and from region-to-region; however, 'Change is inevitable, and change generates many stresses' (Ibid.), which at occasion is likely to influence the states' dysfunctional behavior, responses to different incidents thereby creating more stress, uncertainty and 'dangerous instabilities'(Ibid.). According to Ronald Lehman, if the situation is managed efficiently then it can enhance strategic stability and prevent dangers (Ibid.). In South Asian environment, unfortunately, stress, uncertainty, instabilities and dysfunctional behavioral patterns are clearly visible on the horizon, which is likely to negatively undermine the stability of both India and Pakistan. After the overt nuclearisation of South Asia, both countries had crafted divergent strategic trajectories for their distinct strategic objectives. The Indian policymakers demonstrated propensity to reassert its nuclear deterrence credibility by exploiting its conventional superiority by evolving a 'Cold Start Doctrine' (CSD) in 2004 prima facie for an offensive military undertaking against Pakistan (Ladwig III 2008, 158). 'India...has a declared policy of No-First Use (NFU) of nuclear weapons; nonetheless India may consider launch-on-warning (LOW) strategy,' writes M. Aminul Karim, 'as it is also equipped with the state-of-the-art Israeli Elta Green Pine early-warning and fire-control radar, a Russian airborne early-warning system, and an American-assisted Ballistic Missile Defence (BMD)' (Karim 2014, 38). In addition, since 1998 India is indigenously developing a ballistic missile defence (BMD) system to deal with multi-dimensional threats (Chengappa 2006). India's plan includes multilayered defence contingencies against the incoming ballistic missiles with the Prithvi Air Defence (PAD) to intercept high-altitude targets at the distance of 50-80 kilometers, and with the Advanced Air Defence (AAD) missile for the low-altitude targets at 15-30 kilometers. For instance, in August 1999 with the approval of the Indian Prime Minister, experts had evolved a Draft Nuclear Doctrine (DND) with NFU commitments, which in November 1999 Jaswant Singh, the former Foreign Minister, revealed that DND was 'not a policy document of...India;' in 2003 Delhi diluted NFU by saying that it could retaliate against chemical and biological use against its armed forces personnel; and in October 2010, Shivshankar Menon, National 
Security Adviser, remarked that NFU was only effective in respect to non-nuclear weapon states (NNWs). This instead of creating more transparency regarding its NFU policy, on the contrary, has generated more ambiguity.

In contrast, Pakistan apparently responded by fine-tuning its strategy of integration of non-strategic nuclear weapons (NSNW), also commonly called tactical nuclear weapons, into its doctrinal calculus to neutralize offensive Indian military undertaking (Khan 2011). Pakistan's battlefield-use nuclear posture appears to be an endeavor to prevent India to 'exploit gap' in Islamabad's 'nuclear-deterrence posture,' writes Mark Fitzpatrick. He observes that Pakistan has lowered its nuclear employment threshold in view of existence of asymmetrical equation between the two rivals, and India's evident designs to initiate a limited conventional conflict with the former. This would increase the prospects of miscalculations and lead to failure of nuclear deterrence in a crisis (Fitzpatrick 2014, 50). This does not necessarily indicate that Pakistan's adoption of an 'offensive-deterrence posture' would lower the threshold or enhance the prospects of a nuclear conflict (Khan 2011, 21). It would compel its adversary to take into account the cost and benefit analysis before undertaking a flawed doctrine, to impose a limited war on a nuclear-armed rival, Pakistan (Ibid., 22). For such a volatile regional situation, Mesquita and Riker wrote that 'the victim of a strategic nuclear attack will respond with a strategic nuclear retaliatory strike,' whereas, 'a victim of a conventional or limited nuclear strike will respond either with a limited strike (conventional or nuclear) or with a strategic nuclear strike' (Mesquita 1983, 293).

Such nuclear employment strategy would be an appropriate policy to defend Pakistan's territorial integrity. Possession of an offensive-deterrence strategy would go long way in holding adversary's 'Cold Start' type-doctrines at bay (Khan 2011, 28-33). As long as mutual mistrust and unresolved disputes are persisting, the chances of miscalculations and misperceptions would continue to exist (Fitzpatrick 2014, 50). Moreover, such exacerbation of crises would always leave a room for the 'crisis-management role,' which was frequently played by U.S. in different crises from 1986-87 Brasstacks through to 1990 Kashmir, 1999 Kargil, 2001-02 'Twin Peaks,' and 2008 Mumbai attack (Ibid., 51-64). In such a complex environment, and with the growing estrangement in their bilateral relations, unfortunately, the element of 'stability-instability paradox' (Krepon 2004) is expected to persist.

Since the onset of the 'Second Nuclear Age' (Bracken 2012), the traditional concept of triad consisting of land, air, sea is also undergoing transformation. In the post-9/11 world, for instance, the U.S. policymakers are refining the 'New Triad' comprised of 'both nuclear and advanced conventional weapons; proposals for conventionally armed intercontinental ballistic missiles; and, more generally, the 
concept of Prompt Global Strike.' This vividly reflects that there is a growing conviction that 'advanced conventional capabilities can substitute for some missions previously relegated solely to nuclear weapons' (Gerson 2009, 32). It is generally perceived that, U.S. security strategy is reducing its over-reliance on nuclear weapons by expanding the notion of its 'strategic deterrence' by effectively integrating the modern technologically advanced conventional weaponry, including to use diplomacy, economic clout, and the information age's instruments to evolve a robust $21^{\text {st }}$ century-centric deterrence by shifting its reliance on strategic conventional weapons. This seems to be in harmony with the traditional concept of 'deterrence by denial' crafted to prevent adversary the privilege of achieving its political or military objectives (Snyder 1961, 14-16). During the Cold War, the deterrence notion was synonymously used in the context of nuclear weapons, which had evolved from the nuclear weapons dominated strategy of 'Massive Retaliation' of the 1950 os to the 'Flexible Response' that had comprehensively integrated both the nuclear and conventional capabilities (Gerson 2009, 34). But by 1980 s, a debate had commenced concerning the growing role of strategic conventional weapons (Huntington 1984; Mearsheimer 1983, 2; Mearsheimer 1982, 3-39). It was after the end of the Cold War (1989) and the demise of the former Soviet in 1991, which dramatically influenced the significance of strategic conventional weapons, and the evolution of technologically advanced weapons to meet the challenges and the threats of the post-Cold War era that were previously performed by nuclear weapons (Perry 1991; Allan 1994; Guertner 1993; Cropsey 1994; Oelrich 2005). Gerson writes that, 'Conventional deterrence also plays an important role in preventing nonnuclear aggression by nuclear-armed regimes' (Gerson 2014, 36). He further observes that, 'conventional deterrence can be an important mechanism to limit options for regional aggression below the nuclear threshold' (Ibid.). John Mearsheimer further taking this debate forward writes, that one of the principal architects of conventional deterrence theory '....is best served when the attacker believes that his only alternative is a protracted war: The threat of a war of attrition is the bedrock of conventional deterrence' (Mearsheimer 1982, 64; 206-207).

Pakistan's primary objective behind acquisition of nuclear weapons was to prevent India's larger conventional strength to impose its sway (Khan 2000, 103121). India's chief motivations to acquire nuclear potentials were to use it as an instrument and symbol of prestige to raise its stature as a great power in the international political systems (Ibid., 68-96). Since independence, the Indian policymakers considered nuclear capability critical in order to 'become a peer of the other Nuclear Weapon States' (NWS). Most significantly, the Indian elites were convinced that 'non-nuclear India would continue to rely for its security on 
the NWS' (Ibid., 69). To defend this rationale, India's eminent strategist, K. Subrahmanyam compared the status of non-nuclear India with 'a case of an exceedingly old woman advocating chastity and virtue' (Ali 1984, 24-25). As it is evident since the days of the Peloponnesian War, every country's 'Strategy is really all about...fear, honor, and interest' (Strassler 1976, 43). As elaborated in the previous paragraphs, the strategic stability concept needs to be dispassionately considered holistically in the swiftly changing political and strategic dynamics (Walton \& Gray 2014, 85).

\section{REGIONAL STRATEGIC MATRIX}

In contemporary world, strategy is synonymous with effective employment of all instruments of national power, including economic, industrial, technological, and natural resources, system of governance and internal cohesion, diplomacy, military potentials, and educational R\&D that directly influence the pursuit of political aspirations of a state (Heuser 2010, 36). Since antiquity, the states had aptly utilized its resources in harmony with the military employment strategy toward their larger national political goals. Even the military victory was not considered worth pursuing if it was 'not put to good use politically' for the larger geopolitical, economic and military advantages of a state (Ibid., 38). All modern strategists, including Niccolo Machiavelli, Carl von Clausewitz, Bernard Brodie, Albert Wohlstetter, Henry Kissinger, Thomas Schelling, Andre Beaufre, and many other theorists like Kenneth Waltz, John Mearsheimer, Lawrence Freedman, and Scott D. Sagan considered the states' political aims critical elements in pursuit of their strategic polices (Heuser 2010; Baylis and Garnett 1991). In this perspective, one anonymous strategist belonging to Emperor Justinian I's sixth century writes: 'Strategy teaches us how to defend what is our own and to threaten what belongs to the enemy.' Even today, this principle is still in vogue, and geostrategic metrics of region is visibly premised on this philosophy.

In South Asia, Indian policy seems to be premised on the principles of triggering an arms race in South Asia (Narang 2013, 155), and 'encirclement' of Pakistan (Joshi 2010, 155). India's five myths associated with its nuclear posturing: credible minimum deterrence; claimed possession of nuclear arsenal in a disassembled position; no-first use policy; the role of Indian political elite in determining its nuclear posture; and the security of India's nuclear infrastructure, are further thinning out the 'strategic guidance in Indian nuclear posture' thereby swiftly igniting an arms race between the two rivals (Narang 2013, 155). According to Military Balance 2013, 'India's defence policy retained a substantial focus on 
deterring Pakistan, primarily through the larger country's nuclear-weapons capability,' which is swiftly increasing its conventional military capabilities vis-à-vis Pakistan (The military Balance 2013). India's total defence spending for the financial year 2012-13 in Indian rupees was 2.1 trillion (Ibid., 297). In fact, it is 1.99 percent of its total GDP (Ibid., 263). India increased its defence expenditure by 7.7 percent for 2015-16 in comparison to 2014-15 (Behera 2015; Global Security Organization 2015; Panda 2015). In the case of Pakistan, its total defence expenditure in 2011 was rupees 469 (\$5.47) billion. For the year 2013, India's and Pakistan's total defence expenditures were: $\$ 36.3$ and $\$ 5.89$ billion, respectively (Mitra 2014). India's increasing tendency to enhance its military muscles is purportedly designed to augment its defence and foreign policy potentials in the wake of swiftly changing strategic significance of Indian Ocean that accounts for almost half of seaborne container traffic; over forty percent of petroleum passes through the Strait of Hormuz; and the Strait of Malacca witnesses over fifty percent world's merchant ships plying through it (Kaplan 2011). This accords a huge criticality to the Indian Ocean and the littoral states in the geopolitics of region. Moreover, this also gives it an added importance due to its invertebrate link to the global 'arc of crisis' stretching from Arctic to the Greater Middle East (Ibid., 6). Thus, truly converting the Indian Ocean into a 'symbol of universal humanity,' comments Sugata Bose (Bose 2006, 10; 34). In this emerging geostrategic transformation, India is aspiring to improve its capabilities in the realms of carrier aviation, space surveillance, and cyber in collaboration with the U.S. with a view to control the commons in the Indian Ocean region, and to play a 'leading' instead of a 'balancing' power role in the $21^{\text {st }}$ century (Huntsman Jr. 2015).

It would not be an exaggeration to state that, whosoever controls the straits of Hormuz, Bab-el-Mandeb to Malacca in the present century would regulate the geostrategic imperatives of the region. To achieve this objective, apparently U.S. and India have already evolved convergence since the formulation of their strategic partnership architecture in January 2004 when they had a 'Next Steps in Strategic Partnership' (NSSP) to pave way to formalize a joint collaboration framework for nuclear, space, and latest technologies R\&D. Subsequently, it was followed by signing of a ten-year New Framework for the U.S.-India Defence Relationship accord in June 2005, which laid the foundation-stone for cooperation in defence and security related fields. Moreover, the orbit of their strategic relationship included joint R\&D projects, and Defence Policy Group was set-up to further streamline the contours of future strategic partnership's orbit (Latif 2012,50 ). Why there is an intensification of rivalry and the growing significance of the region? For instance, from future perspective, by 2030 world's energy requirements would increase by fifty percent in which China and India is expect- 
ed to consume half of it. This would make India the fourth largest consumer of energy after U.S., China and Japan. By 2025, India is likely to become the third largest consumer of oil (Kaplan 2011, 7-8).

'The Indian Ocean is where the rivalry between the United States and China in the Pacific interlocks,' writes Kaplan, 'with the regional rivalry between China and India, and also with America's fight against Islamic terrorism in the Middle East, which includes America's attempt to contain Iran' (Ibid., 9). Hence, making the Indian Ocean as a part of U.S. 'Strategy Vision' of 2008 where U.S. competitive presence is considered imperative in order to meet the diverse challenges, which in their perception is likely to become the future theatre of competition (Ibid.). On the other hand, China and India too have shifted their attention to acquisition of sea capabilities, not necessarily for energy security, but ostensibly to increase their seaborne out-reach and to acquire a great power status (Ibid.). According to James Holmes and Toshi Yoshihara, it is expected to put under stress the U.S. sea primacy in the coming decades (Ibid.). Kaplan observes that China is endeavoring to rise 'vertically' toward the Indian Ocean; while India is moving to acquire horizontal influence from East to West (Ibid., 10). Beijing in accord with its 'string-of-pearls strategy' is acquiring facilities at the ports of Gwadar (Pakistan), Hambantota (Sri Lanka), Chittagong (Bangladesh), and Coco Islands (Myanmar) (Ibid). India on the other hand, in spite of existence of ostensibly strong strategic ties, has forged a strategic out-reach with Iran. In this context, New Delhi is assisting Tehran in developing its Chabahar port with intent to link it with Afghanistan's province of Nimruz, and to reduce Kabul's reliance on Pakistan. This would provide India a critical position in the affairs of Afghanistan right through to Caspian Sea, Kazakhstan, and to other Central Asian hydrocarbon resources that are vital for its future industrial and economic growth (Ibid., 1314). In addition, it would give India a decisive leverage in the future political contours and anti-terrorism drive against $\mathrm{Al}$ Qaeda in Afghanistan after the materialization of exit plan of the U.S.

All these strategic changes are expected to elevate India's stature in league with the other major regional and great extra-regional powers in the coming years. Currently, the world is witnessing marked transformation in the field of socioeconomic, technological, ideological-religious moorings that would impact the strategic stability in conjunction with military power potentials of the states. Furthermore, there is a growing trend to forge alliances between the great and medium size powers, which is characteristically impacting the security environment of the area and, thereby putting the whole concept of strategic stability on more fluid grounds (Walton and Gray 2014, 109-110). Therefore, medium size country like Pakistan should attempt to accordingly restructure its foreign and 
security policy by keeping in view the rapidly changing world under the influence of socioeconomic, technological, and information age's revolutionary developments that are poised to influence the whole spectrum of geopolitical and military transformations. In such fluid circumstances, Pakistan instead of bandwagoning should endeavor earnestly to balance its policy in conformity with the changing dynamics of the globalized world in which balancing strategy could prove more productive than the bandwagoning alternative (Mearsheimer 2001, 139). Ostensibly, Pakistan has given China port facilities in Gwadar, not necessarily to become a part of latter's 'string-of-pearl strategy' (Kaplan 2011, 10, 11), rather as an economic and geostrategic imperative to balance its foreign and security policy in the quickly changing regional security dynamics. At the heart of Indian Ocean and South Asian politics, lies the U.S. supposed policy of 'containment' of China. While some experts have suggested that, U.S. should be pursuing a policy of 'balancing' instead of containing - as Beijing's rise essentially cannot be checked due to its economic success (Tellis 2014, 32). In the viewpoint of Ashley Tellis, 'China...cannot be defeated presently through a strategy of containment;' hence, suggested adoption of 'an alternative strategy, that of balancing China without containing it' (Ibid., 85). He elaborates that, unlike the previous U.S. policy of using war to contain the then peer competitors - Nazi Germany and Japan, now this option of employment of force is not a rational option vis-àvis China on 'practical and moral reasons.' Moreover, constricting China's economic rise in globalized world would too entail heavy cost for the U.S. economic growth primarily due to interdependent nature of modern day trade and commerce (Ibid., 33). The globalization has resulted in transfer of technologies, innovations, from the developed to newly industrializing nations like China, which has taken advantage of this technological shift that triggered its economic growth, increased exports and gross domestic product (GDP), enabled it to give credit to other countries. However, over ninety percent of Chinese high-technology exports are of foreign origin (Beckley 2012, 42-43). Presently, U.S. technological edge both in qualitative and quantitative terms is unprecedented that continues to elevate its geopolitical stature (Wohlforth 1999, 17). Therefore, it can be deduced that, China is rising economically but in technological, geopolitical, soft and hard-power terms, it is still far away from 'catching-up' with the U.S. (Chestnut and Johnston 2009).

In geopolitical and regional terms, the U.S. policy of weaving in the littoral states of the Indian Ocean and Asia-Pacific like Japan, South Korea, Philippines, India, Vietnam, Singapore, Australia, and Indonesia into a cooperative strategic partnership architecture is strengthening its strategic outreach and, on the contrary, is triggering Chinese misgivings about the former's policy vis-à-vis the lat- 
ter. Although U.S. had on different occasions attempted to highlight that this collaboration framework is not against China, rather it is being materialized to stabilize the value-based relationship in view of the political and economic situation. In diplomatic realm, relations between U.S. and China 'have gone from being generally positive at the strategic level among the great powers to extremely difficult,' stated Kurt M. Campbell, a former Assistant Secretary of State who had previously assisted President Obama in formulating the Asia strategy. As per Campbell, in 2014: 'It's a much more challenging strategic landscape' (Nakamura 2014). In spite of U.S. Vice President Biden's pleas in 2014 to China to desist from any provocative action in sea, China continued its naval maneuvers at sea. Earlier, President Obama's and the then Secretary of State, Hillary Rodham Clinton's Strategic Vision of 'pivot' in 2011 to contain China were launched (Ibid). Instead of extracting itself from Middle East, Iraq, and Afghanistan, in 2014 U.S. was also drawn into another arena, Eastern Europe - Ukraine and Crimea (Baker 2014). In 2015, U.S. and eleven Pacific Rim countries established the Trans-Pacific Partnership (TPP) free trade. The U.S.-ASEAN (Association of Southeast Asian Nations) in November 2015 meeting reportedly had decided to convert it into a strategic partnership. These developments appear in line with Pentagon's 2012 plan to move its sixty percent of its air and naval assets to Asia-Pacific region by 2020, which includes establishment of marine air base in Vietnam, Japan, and Indonesia.

Basically, the state of economic interdependence would continue to be guided by sustaining a fine balance between the vulnerabilities of the countries on the poles of economic compulsions, and the military containment imperatives to curtail the rise of China (Keohane 1977). Therefore, to balance the economic and strategic poles in line with U.S. containment vision is expected to persistently keep the dynamics of regional politics on wavering grounds. Hence, the countries of Indian Ocean, including India and Pakistan, would too be inclined to keep their strategic options open by trying to balance their respective foreign and security polices between China and U.S. due to their economic and strategic imperatives in the existing fluid situation. The national power matrix would continue to be premised on multifaceted factors, because, military power is directly linked with the economic health of a country (Tellis 2000). The military strategy has to be integrated in harmony with the economic systems and resilience of the state (Beckley 2012, 57). For instance, U.S. budgetary constraints are limiting its capability to launch 54 required amphibious ships for Pacific-Command (PACOM) to make its pivot plan operational. Right now, U.S. has 29 amphibious ships in the region (Mazza 2014). This aspect was too amplified by the U.S. PACOM Commander, Samuel Locklear, in a testimony maintained that the forward- 
deployed forces 'at the great expense of the readiness of the follow-on force and the critical investments needed for these forces to outpace emerging threats, potentially eroding our historic dominance in both capability and capacity' (Ibid.). In spite of U.S. technological edge, the 'surplus wealth' (Knorr 1956, 231239) metric is still quite critical to operationalise the 'pivot' policy in the coming years. While Chinese economic rise is expected to move consistently on vertical axis and, on the other hand, U.S. on horizontal matrix - to expand the capability and bases of its forces in the Indian Ocean, Far East, and Pacific regions. All these lopsided developments would influence the South Asian security and power equation as well (Khan 2013).

\section{SECURITY PURSUITS}

Since the 1950s right through to the demise of the former Soviet Union, Pakistan had been a part of U.S.-sponsored system of alliances to contain the then threat of Communism. Since the disintegration of the former Soviet Union, Pakistan has been consistently in search of security-driven measures and to astutely employ its nuclear weapons capability on the principles of sustenance of credible nuclear deterrent posture in order to hold India's conventional power at bay. In fact, in the wake of discriminatory and in clear contravention to the non-proliferation norms and principles of the Nuclear Non-proliferation Treaty (NPT), President George W. Bush in 2005 signed agreement that led to adoption of India-centric legislation by the U.S. Congress and Nuclear Suppliers Group's (NSG) waiver in 2008 on the rationale of Delhi's supposed nuclear responsibility and stewardship profile and, in spite of its far from perfect non-proliferation track record (Albright 2006, 162). Albeit, in the realm of nuclear safety and security, nuclear diplomacy, including Pakistan's contribution in the multilateral forums like Nuclear Security Summit (NSS), and existence of a multi-tiered system to prevent proliferation of nuclear materials and technologies, too deserve exception to end its nuclear marginalization. To acquire a 'nuclear legitimacy' (Fitzpatrick 2014, 162), does Pakistan have to follow the traditional principles of towing the predominant state's line in the regional and world affairs? Not necessarily. One, Pakistan's destiny is intractably linked to the regional trends in strategic dynamics, which at the moment does not favor it to go in the opposite direction to the regional developments. Two, Pakistan cannot discount the significance of regional countries especially China, India, Afghanistan, Iran, and the Middle Eastern and Gulf Cooperation Council (GCC). Three, bandwagoning (Mearsheimer 2001, 139) would be counterproductive in view of the fluid regional situation, as discussed 
in the preceding section. The viable alternative strategy for Pakistan is to pursue economic and geostrategic developments to balance its national interests in the swiftly changing regional security dynamics. Four, the scourge of terrorism is a transnational problem, which is expected to grow out of control after the withdrawal of U.S. and its allies' forces - after their failure to stabilize the war torn Afghanistan. In the dramatically changed environment of 2015, Pakistan need to dispassionately evaluate the outcome of simmering civil wars in Syria, Iraq, and Yemen, and to balance its foreign and security policy between the Saudis and the GCC states in the wake of ensuing detente between US and its allies with Iran, and to protect its geo-economic stakes astutely by maneuvering out of push and pulls of the regional states to align with them. Pakistan's stature could be significantly enhanced by facilitating a conflict resolution diplomacy that could contain the expanding orbit of narrow religious-sectarian menace toward South Asia, and the geopolitical struggle between the House of Saud of Saudi Arabia-GCC states and Iran.

Most notably, after the 9/11 terrorist attacks, and the subsequent U.S. invasion of Afghanistan had pushed the entire terrorism network then operative in Afghanistan into the Pakistani tribal areas. This has multiplied Pakistan's woes, internally destabilizing it to an extent that resulted into heavy human and material losses. Internal destabilization of Pakistan is also being alleged to Indian support to terrorist outfits (Cheema 2013). Now, the regional situation is sandwiched between nuclear politics and the realities of terrorism, which is further aggravated due to absence of a dialogue, non-existence of arms control measures, persisting mistrust, and the rise of radical political forces both in India and Pakistan in the form of Bharatiya Janata Party (BJP) (Singh 2014) and the Taliban, respectively. Unfortunately, such ultra-radical forces are expected to silence, if not eliminate altogether, the liberal voices of South Asia. Therefore, both countries national interests lie in neutralizing such forces from extinguishing the light of rationality, enlightenment and liberalism, and to minimize the gulf of mistrust and divergent civilizational and religious trajectories in order to stabilize their bilateral relations and nuclear deterrence postures. In essence, the regional geopolitical situation is linked to the Persian Gulf, Indian Ocean and Asia-Pacific in an overarching strategic equation in which China, India, Pakistan, Afghanistan, and Iran are an integral part of this quadrilateral strategic cycle. Apparently, the future developments in quadrilateral strategic cycle is expected to construct and make sense of the world of our own making (Onuf 2013, 21-39), that is likely to be influenced by the overarching string of strategic developments taking place in the larger Persian Gulf, Indian Ocean, and Asia-Pacific interlinked regions into a super security complex (Buzan and Waever 2007, 62). The super- 
complexes emerge as a result of 'strong interregional level of security dynamics arising from great power spill over' effect on to the other adjoining regions (Ibid.). In this context, Alexander Wendt also observes that constructivism theory of international relations is a type of 'structural realism' (Wendt 1999, 1, xiii) that assists in understanding the prevalent world situation through a realistic and holistic lens. The South Asian regional security complex is quickly transforming from bipolarity to unipolarity due to India's rise as a stronger state in comparison to Pakistan. This is transforming the regional political configurations by making it much more outward looking with stronger India emerging on the horizon of interregional geopolitics. Simultaneously, India's economic and strategic clout is increasing due to its convergence with the Asia-Pacific geopolitical factors where China's rise is too being viewed with skepticism by India, U.S. and its allies, both in E.U. and Asia-Pacific (Ibid., 3-4). Although, India still has serious bilateral dispute over 2500 miles border with China and (Kaplan 2011, 127), on the other hand, Pakistan is likely to tie down India in the South Asian and Indian Ocean affairs. Because, both India and Pakistan are still 'at each other's throats' and (Buzan 2011, 5). The regional rivalry is expected to further exacerbate when India might become the third largest economy of the world in the coming decades. In the military realms, it has inducted two aircraft carriers, and plans to have three more by 2022 along with a flotilla of six more submarines and thirtyone warships for its blue navy (Kaplan 2011, 126-127). The Indian naval expansion from its 244 islands of Andaman-Nicobar archipelago appears to be a part of a broader strategy to gain a predominant role in the Indian Ocean from Hormuz to Strait of Malacca (Ibid., 125-126). As per Mohan Malik, this has created a 'Hormuz dilemma' for India due to Pakistan-China project to develop Gwadar ostensibly to regulate the critical choke points of Gulf of Oman and Hormuz. On the other hand, similarly 'Malacca dilemma' could intensify Chinese concerns due to emergence of U.S.-India strategic equation with growing reliance on their respective sea assets, which are liable to play a decisive geostrategic role from Indian Ocean to Asia-Pacific (Malik 2008). This naturally accords India a counterbalance equation vis-à-vis China, which both India and U.S. are employing for their respective national interests (Luce 2007, 287).

India is trying to 'position itself' into the 'emergent Asian super region' by adroitly linking itself with the 'developments... at the global level' (Ibid., 2). On the other hand, the state of economic interdependence between India and China is expected to moderate their bilateral relationships. While the balancing SinoIndian economic interdependence with Beijing's cordial relations with Pakistan, would keep their bilateral relations on precarious ground. But, despite India's rise, it is still entangled with multiple disputes with the neighboring countries, 
including China and Pakistan. This continues to tie India down like a 'huge fish,' remarks Buzan 'in a small bowl in South Asia' (Ibid., 17). Ostensibly, the ruling Indian elite have failed to understand that great power credentials require a holistic perspective in which they have to leave behind the traditional regional security paranoia and historical baggage (Ibid., 22). Hence, it would be quite difficult, if not impossible, to balance India's volatile profile from South Asia to Far East notwithstanding its concurrence with the U.S. Asia Strategic Vision (Nakamura 2014). Although, rise of India in economic, military and diplomatic fields is transforming the South Asian RSC from 'bipolarity to unipolarity' (Buzan and Waever 2007, 115-118); therefore, India's apparent policy to transcend from the South Asian region toward the other regions without resolving serious disputes with Pakistan and China - would continue to tie it down in a perpetual dangerous issues with its nuclear peers (Buzan 2011, 3). In essence, the trends that confront India-Pakistan in a peculiar South Asian security dynamics are based on their distinct strategic cultures that were molded by the perennial hostility ingrained in the ethos of their divergent civilizational, religious, and cultural traditions. The volatile nature of relationship based on diverse foreign and security policy goals was primarily influenced by these factors.

Pakistan despite being mired in internal unrest, violence, terrorism, economic stagnation and rampant corruption, continues to be a resilient country, which still possesses both conventional and nuclear military strength thereby making it impregnable for its adversaries to surmount in contemporary situation (Lieven 2011, 4, 7). The state's strength to sustain different internal and external pressures continues to keep the country on the road to modernity and development (Ibid., 4). As observed in the previous sections, that Pakistan's strategic significance is perennial that makes it critical for the U.S., E.U. and China to sustain their long-term engagement with it (Ibid., 481). Moreover, the international community realizes the significance of facilitating a peaceful solution to the Kashmir dispute (Ibid., 480), which would go long way in stabilizing India-Pakistan relations and the regional security architecture. In the case of instability in Pakistan, all the regional countries, including Afghanistan, Iran, China, and India would too have negative implications (Markey 2013, 236). Notwithstanding the multiple problems, Pakistan is a major nuclear armed country whose strategic significance cannot be discounted. Therefore, it is crucial for the other countries, particularly the U.S. and E.U. to pursue a balanced policy by building architecture of cooperative bilateral relationship with Pakistan. For that reason, there is an imperative need to build 'bridges between the people of Pakistan and the United States' (Ibid., 236-37). In this context, U.S. can play a constructive role to normalize India-Pakistan relations with a view to put their divergent foreign and 
security policies on more positive trajectories. The swift technological changes and the strategic stability concept of the Cold War era has to be taken holistically with the intention of taking into account the emerging capabilities of offensive strategic conventional weapons capabilities that could be employed to obliterate opponent's nuclear forces, or may be its ability to operate them in a crisis. This technological transformation of information age has simultaneously linked the viability of nuclear deterrence to other factors like deterrence effectiveness through economic, military, R\&D and educational potentials, diplomatic clout, bureaucratic and institutional strength and feasibility, domestic politics, and the alliance politics. Nowadays, the technological developments, economical and industrial changes are performing the role of an agent of transformation.

\section{EMERGING TRENDS}

In the present century, whosoever would control the straits of Hormuz, Bab-elMandeb to Malacca is expected to regulate the geostrategic imperatives of AsiaPacific. In fact, by 2030 world's energy needs are expected to increase by manifolds in which China and India would consume nearly half of it. At the same time, both China and India have shifted focus toward acquisition of sea capabilities, not only for energy security, but also to expand their seaborne strategic outreach with a view to acquire a great power status. This century is likely to witness an intensification of rivalry between the U.S. and China in the Pacific, and China and U.S.India in the Indian Ocean. According to Chuck Hagel, this is critical in view of the shifting security landscape, which makes its 'partnerships and alliances indispensable as anchors for regional stability.' In this context, Washington furthermore bestows India with a more proactive role in Asia's and region's order, and consider New Delhi's growing military capabilities, and India-U.S. defence relationship essential to ensure 'freedom of navigation in the Indian Ocean' (Hagel 2014). In such circumstances, U.S. considers China rebalancing strategy as a 'reality' vis-à-vis latter's alleged 'destabilizing, unilateral actions asserting its claims in the South China Sea' (Ibid.). On the other hand, Lt. Gen. Wang Guanzhong, Deputy Chief of the General Staff of the People's Liberation Army termed Hagel's remarks as 'groundless' (Baldor 2014). In such a volatile situation, Pakistan may endeavor to poise its policy in conformity with the changing dynamics of the globalized world in which balancing strategy seems to be more productive strategy than bandwagoning.

Presently, India-Pakistan situation is sandwiched between nuclear politics and the reality of terrorism, which in absence of a dialogue, non-existent arms control 
arrangements, perpetual mistrust, and the rise of radical political forces both in India and Pakistan in the form of Bharatiya Janata Party (BJP) and Taliban/terrorist outfits respectively, is likely to further undermine their relationship (Malhotra 2014; Masood 2014). Unfortunately, the ultra-radical political forces and non-state actors are liable to silence the liberal voices of two countries. In this context, some experts have even prophesied that in the event of any major terrorist attack in India, BJP might resort to offensive incursion into Pakistan with some battle group formations (Fitzpatrick 2014). For such developments, it would be logical for Pakistan to integrate the NSNW into battlefield formations to counter the Indian offensive plan of the CSD. In fact, in April-May 2011, India had undertaken a military exercise 'Shoor Veer' to integrate its offensive 'theatre battle concept' into its limited war fighting doctrine (Krepon and Thompson 2012, 12). Such dangerous notions are not only flawed but provocative too, that 'might not deter Pakistan from using its tactical nuclear weapons,' writes Neil Joeck. He further elaborates that Pakistan is already 'expanding its nuclear forces for possible battlefield employment' against any limited Indian military offensive (Joeck 2012; Smith 2012). On the other hand, Pakistan's counter-strategy was reportedly refined in 'Azm-e-Nau' military exercises in 2013 (Krepon and Thompson 2012; ISPR 2013). In such a scenario, pragmatic policy for Pakistan would be to move vertically from its present posture of a minimum credible deterrence to robustly reinforced offensive-deterrence plan with a view to efficiently neutralize the multidimensional threats and challenges being posed to its security. In such circumstances, apparently the nuclear 'red-lines' would be unpredictable and short due to geographical contiguity. In fact, India's policy concerning the NSNW is also 'murky' and its military superiority is more than sufficient to deter Pakistan (Smith 2012, 67). However, vertical deterrence based on the principles of ever ready offensive deployments of Pakistan's conventional and strategic forces would accord it a necessary flexibility to deal with the Indian offensive game plan and the growing military asymmetry. For Pakistan, NSNW in essence would be a force equalizer against India's conventional military edge (Colby 2012, 75-105). Therefore, India-Pakistan's salvation lies in neutralizing the ultra-radical forces that are undermining the voices of rationality and liberalism. It is crucial to abridge the gulf of mistrust and to narrow-down the civilizational and religious trajectories with a view to stabilize their bilateral diplomacy and to stabilize their nuclear deterrence postures.

In spite of countries' increasing interdependence in a globalized world, India and Pakistan are still moving on divergent strategic axis, which unfortunately still continues to influence their foreign and security policies. Though both countries have achieved a state of nuclear deterrence; but, the concept of strategic stabili- 
ty is being dramatically transformed due to technological transformations, growing role of the NSNW, globalization, and the rising significance of geo-economics in international politics. This has too influenced the South Asian regional strategic matrix that is speedily being linked to the super security complex all the way from Middle East to East Asia. In this environment, India's economic and strategic rise is according it a critical strategic outreach from the Indian Ocean to AsiaPacific, while its outstanding disputes with the regional countries, especially with China and Pakistan - still continues to tie it down. Rise at the global level is only conceivable when the regional strategic situation is in the favor of potential candidate. Therefore, in essence, the rise logically should be premised on the principles of pragmatism and the idea (Brodie 1973, 452) of sustenance of stability in one's immediate surroundings in amalgam with a display of 'strong' and 'decisive' behavior at a critical point (Clausewitz 1976; Jomini 1992).

\section{CONCLUDING REMARKS}

The paper has delineated various facets of regional and extra-regional developments, including the geo-economic, geopolitical and technological transformations that are immensely molding the regional situation in parallel with emergence of China and India as the stronger powers of the East and South Asian Regional Security Complex (RSC), respectively. It argued that both India and Pakistan since independence had traversed on divergent strategic trajectories, which consequently expanded the gulf of bilateral misperceptions, which persistently negatively impacted the emerging strategic structure of Subcontinent. In realpolitik, every state's strategic significance is determined through the lens of prevalent global and regional situation, threat perceptions, national interests, geo-economics, geostrategic transformations and conflicting insights. However, notwithstanding the South Asian RSC, the major regional countries like China, India, and Pakistan still have a long list of unsettled territorial, water, and other disputes that are continuously complicating their bilateral relations, escalating the 'stability-instability paradox,' widening the expanse of military asymmetry that is particularly complicating the India-Pakistan relationship, and motivating them to crafting of offensive conventional and nuclear posturing thereby creating instability both at tactical and strategic levels. This mutual animosity has generated a spiral of 'fear of each other' that had clouded their mutual perceptions, impacted their behavior and relationship. It thereby locked them into a perpetual cycle of 'security dilemma.' The lopsided situation has moreover generated multi-dimensional security complexities in which the Indian policymakers are 
focusing on expansion and modernization of its conventional forces that is resultantly triggering an arms race, and generating a perception of 'encirclement' in the mind of Pakistani policymakers.

The Indian policymakers demonstrated tendency to reassert India's nuclear deterrent credibility by using its conventional military superiority by evolving a flawed strategic doctrine of 2004 'Cold Start' prima facie to launch an offensive military operations against Pakistan. On the other hand, Pakistan is poised to fine-tune its strategy in conjunction with integration of NSNW into its doctrinal calculus to counterbalance the offensive Indian military doctrine and to reinforce its nuclear deterrent posture at every tier - from conventional-cum-tactical to strategic plane. Clearly, Pakistan's strategic doctrinal response is expected to compel its adversary to take into account the cost and benefit analysis before initiating a flawed doctrine to impose a limited war on Pakistan. However, in view of persistence of mutual mistrust and festering unresolved disputes, the prospects of miscalculations and misperceptions would continue to linger on. In such a complex environment, and with the growing estrangement in IndiaPakistan's relations, the South Asian nuclear deterrence is not likely to overcome the regional 'stability-instability paradox,' and thereby persistently accentuate both countries' threat perceptions and security dilemmas. Furthermore, technologically advanced conventional weapons are too reducing the traditional overreliance on the nuclear weapons for deterrence and to achieve political objectives. The notion of strategic deterrence now includes, effective integration of modern technologically advanced stealth conventional weaponry, space reconnaissance, flexible targeting, responsive and assertive command and control system, diplomacy, economic base, and the information age's others instruments that would define the robust $21^{\text {st }}$ century-centric conventional and nuclear deterrence and doctrines (Fortmann and Stefanie Von Hlatky 2011, 314), which would reduce over reliance on strategic nuclear weapons. The powerful state of South Asia, India, is clearly trying to acquire an extra-regional role. This persistently motivates New Delhi to invest heavily in the conventional and strategic weapons R\&D, which currently makes it the largest buyer of offensive strategic weapon systems, and has also aligned with the powerful states. On the other hand, Pakistan is ostensibly attempting to sustain its credible deterrent posture from an offensivedefensive perspective without necessarily endeavoring to acquire a nuclear or conventional parity against India.

Since 1998, both countries had initiated endeavors to formalize architecture to sustain some semblance of strategic stability. In this context, they had undertaken multiple initiatives, including U.S. Deputy Secretary of State Strobe Talbott led a strategic dialogue in July 1998; Pakistan in September 1998 initiated a non- 
paper titled, 'Strategic Restraint Regime' (SRR) and a mutual pact to India - not to produce or acquire submarine-launched ballistic missiles (SLBMs); 1999 Lahore Declaration and the Memorandum of Understanding (MoU) was signed to strengthen the web of nuclear confidence building measures (CBMs); and in 2004 Pakistan proposed to recommence Lahore MoU under a Composite Dialogue process. The Lahore MoU had provided a fairly encouraging framework to stabilize strategic environment, and to expand the ambit of Lahore MoU. Unfortunately, the subsequent developments of 1999 Kargil War, 2001-2002 crises, India's 2004 CSD, 2008 Indo-U.S. nuclear agreement and Mumbai attack, and the start of a debate in India and Pakistan to induct NSNW, has further complicated the South Asian strategic dynamics. The issue related to the stabilityinstability paradox is further influencing the transformation in military technologies and, whereas the increasing pace of economic interdependencies, influx of non-nuclear strategic weapons, the expanding role and influence of the super RSC, growing threats of terrorism and non-state actors, and the military imbalance are adding more complexity to South Asian nuclear deterrence paradigm. In essence, to understand the dynamics of India's and Pakistan's strategies based on dramatically opposite principles - offensive and offensive-defensive respectively, requires more in-depth study by taking into account the foregoing multiple factors.

\section{REFERENCES}

Acton, James M. 2014. "Reclaiming Strategic Stability.” In Elbridge A. Colby and Michael S. Gerson. eds. Strategic Stability: Contending Interpretations, Carlisle, PA: U.S. Army War College Press.

Albright, David, and Susan Basu. 2006. "Neither a Determined Proliferator nor a Responsible Nuclear State: India's Record Needs Scrutiny.” Institute for

Science and International Security (April 5). Accessed at http://www.nci.org/o6nci/o4/indiacritique.pdf (January 15, 2015).

Ali, Akhtar. 1984. Pakistan's Nuclear Dilemma: Energy and Security Dimensions. Karachi: Economist Research Unit.

Allan, Charles T. 1994. "Extended Conventional Deterrence: In from the Cold and Out of the Nuclear Fire?” Washington Quarterly 17(3), 203-233.

Art, Robert J. 1982. "The Role of Military Power in International Relations.” In B. Thomas Trout and James E. Harf. eds. National Security Affairs: Theoretical Perspectives and Contemporary Issues, New York: National Strategy Information Centre, 14. 
Baker, Peter. 2014. “Obama Takes a Page from Cold War Playbook.” The Express Tribune (April 21).

Baldor, Lolita C. 2014. "Hagel spars with China over territorial disputes." Yahoo News (May 31). Accessed at http://news.yahoo.com/hagel-spars-chinaover-territorial-disputes-112741162--politics.html\# (December 15, 2014).

Banchoff, T. 1991. The German Problem Transformed: Politics and Foreign Policy, 1945-1995. Ann Arbor, MI: University of Michigan Press.

Baylis, John and John Garnett, eds. 1991. Makers of Nuclear Strategy. London: Pinter Publishers.

Beckley, Michael 2012. "China's Century? Why America's Edge will Endure." International Security 36 (3), 41-78. . 2011. "China's Century: Why America's Edge Will Endure." International Security 36(3), 41-78.

Behera, Laxman K. 2015. "India's Defence Budget 2015-16." Issue Brief of Institute of Defence Studies and Analyses (March 2). Accessed at http://www.idsa.in/issuebrief/IndiasDefenceBudget2015-16_lkbehera_020315.html (March 23, 2015).

Berger, T. 2003. Culture of Anti-Militarism: National Security in Germany and Japan. Baltimore, MD: Johns Hopkins University Press.

Bose, Sugata. 2006. A Hundred Horizons: The Indian Ocean in the Age of Global Empire. Cambridge, MA: Harvard University Press.

Bracken, Paul. 2012. The Second Nuclear Age: Strategy, Danger, and the New Power Politics. New York: Henry Hold \& Co.

Brodie, Bernard. 1973. War and Politics. New York: The Macmillan Co.

Buzan, Barry and Ole Waever. 2007. Regions and Powers: The Structure of International Security. Cambridge: Cambridge University Press.

Buzan, Barry. 2011. "A World Order without Superpowers: Decent red Globalism." International Relations 25(1), 3-25. . 2011. "The South Asian Security Complex in a Decentering World Order: Reconsidering Regions and Powers Ten Years On.” International Studies 48(1), 2.

Buzan, Barry and L. Hansen. 2009. The Evolution of International Security Studies. Cambridge: Cambridge University Press, 187-188.

Cheema, Umar. 2013. "Ex-Indian Army chief admits sponsoring terrorism in Balochistan." The News International (October 21).

Chengappa, Raj. 2006. "The New Guardian.” India Today (December 11).

Chestnut, Sheena and Alastair Iain Johnston. 2009. "Is China Rising?” In Eva Paus, Penelope B. Prime, and Jon Western. eds. Global Giant: Is China Changing the Rules of the Game? New York: Palgrave Macmillan. 
Clausewitz, Carl von. 1976. On War. Princeton, NJ: Princeton University Press. Colby, Elbridge A. 2012. "U.S. Nuclear Weapons Policy and Policymaking: The Asian Experience.” In Tom Nicholas, Douglas Stuart and Jeffrey D. MacCausland. eds. Tactical Nuclear Weapons and NATO, Carlisle, PA: U.S. Army Strategic Studies Institute, 75-105.

. 2013. "Defining Strategic Stability: Reconciling Stability and Deterrence." In Elbridge A. Colby and Michael S. Gerson eds., Strategic Stability: Contending Interpretations, Carlisle, PA: U.S. Army War College Press.

Collins, John M. 1973. Grand Strategy: Principles and Practices. Annapolis: Naval Institute Press, 14-21.

Rice, Condoleezza. 2005. "Remarks at Sophia University." (March 19). Accessed at http://2001-2009.state.gov/secretary/rm/2005/43655.htm (April 17, 2014).

Cropsey, Seth. 1994. “The Only Credible Deterrence.” Foreign Affairs 73(2), 1420.

Duffield, J. S. 1998. World Power Forsaken: Political Culture, International Institutions, and German Security Policy Unification. Stanford, CA: Stanford University Press.

Elman, Colin 1995. "Correspondence: History v. Neo-Realism: A Second Look.” International Security 20(1), 185-186.

Fiammenghi, Davide. 2011. "The Security Curve and the Structure of International Politics.” International Security 35(4), 126-154.

Fitzpatrick, Mark. 2014. “Terrorism isn’t Pakistan's Gravest Nuclear Danger.” The Express Tribune (May 7).

. 2014. Overcoming Pakistan's Nuclear Dangers. London: The International Institute for Strategic Studies.

Fortmann, Michael and Stefanie Von Hlatky. 2011. "The Revolution in Military Affairs: Impact of Emerging Technologies on Deterrence." In T. V. Paul, Patrick M. Morgan and James J. Wirtz. eds. Complex Deterrence: Strategy in the Global Age, New Delhi: Cambridge University Press India Pvt. Ltd.

Inter Services Public Relations. 2013. "Press Release.” (November 5). Accessed at http://www.ispr.gov.pk/front/main.asp?o=t-pressrelease\&date=203/11 /5 (December 10, 2013).

Gall, Carlotta. 2014. "What Pakistan Knew About Bin Laden?” International New York Times (March 19). Accessed at http://www.nytimes.com/2014 /o3/23/magazine/what-pakistan-knew-about-bin-laden.html?_r=o (April 28, 2014).

Gerson, Michael S. 2009. “Conventional Deterrence in the Second Nuclear Age.” 
Parameters 39(3), 32.

. 2014. "The Origins of Strategic Stability: The United States and the Threat of Surprise Attack." In Elbridge A. Colby and Michael S. Gerson. eds. Strategic Stability: Contending Interpretations, Carlisle, PA: U.S. Army War College Press, 14-15.

Gilpin, R. 1986. “The Richness of the Tradition of Political Realism.” In Robert O. Keohane. ed. Neo-Realism and Its Critics, New York: Columbia University Press.

Global Security Organization. 2015. "Medium Multi-Role Fighter Aircraft (MMRCA/MCRA) Multi-role Fighter." (April 11). Accessed at http://www.globalsecurity.org/military/world/india/mmrf.htm (April 30, 2015).

Gray, Colin S. 1996. “The Continued Primacy of Geography,” Orbis 40(2), 247259.

Greenwood, Nicholas and Onu. 2013. Making Sense, Making Worlds: Constructivism in Social Theory and International Relations. Abingdon: Routledge, 2013, 21-39.

Grygiel, Jakub J. 2006. Great Powers and Geopolitical Change. Baltimore: Johns Hopkins University Press.

Guertner, Gary L. 1993. "Deterrence and Conventional Military Forces." Washington Quarterly 16(1), 141-151.

Hagel, Chuck. 2014. “The United States' Contribution to Regional Stability: Chuck Hagel.” London: The International Institute for Strategic Studies (May 31). Accessed at https://www.iiss.org/en/events/Shangri\%20\%la\% dialogue/archive/2014-c20c/plenary-1-d1ba (June 15, 2014).

Hasan, K. Sarwar. 1966. The Transfer of Power: Documents on the Foreign Policy of Pakistan. Karachi: Pakistan Institute of International Affairs.

Hay, Stephen. 1991. Sources of Indian Traditions: Modern India and Pakistan. Vol. II. New Delhi: Viking by Penguin Books India Ltd.

Herz, John H. 1950. "Idealist Internationalism and the Security Dilemma." World Politics 2(2), 157-180.

Heuser, Beatrice. 1991. The Strategy Makers: Thoughts on War and Society from Machiavelli to Clausewitz. Santa Barbara, California: ABC-CLIO.

. 2010. "Strategy before the Word: Ancient Wisdom for the Modern World.” RUSI JOURNAL 155(1), 36-42.

Huntington, Samuel P. 1983. "Conventional Deterrence and Conventional Retaliation in Europe.” International Security 8(3), 32-56.

Huntsman Jr., Jon and Bharath Gopalaswamy. 2015. "Transforming India from a Balancing to a Leading Power.” The National Interest (April 14). 
Accessed at http://nationalinterest.org/feature/transforming-indiabalancing-leadingpower-12624 (April 15, 2015).

Jervis, Robert. 1984. "Deterrence and Perception." In Steven E. Miller ed., Strategy and Nuclear Deterrence: An International Security Reader, Princeton, New Jersey: Princeton University Press.

. 2004. "Hypotheses and Misperception." In Karen A Mingst and Jack L. Snyder. ed. Essential Readings in World Politics. New York: W. W. Norton Company, 193.

Keohane, Robert O. ed. 1986. Neo-Realism and Its Critics. New York: Columbia University Press.

Joeck, Neil. 2012. "Prospects for Limited War and Nuclear use in South Asia." In Michael Krepon and Julia Thompson. eds. Deterrence Stability and Escalation Control in South Asia. Washington: The Stimson Center. Jomini, Antoine Henri de. 1992. The Art of War. London: Greenhill Books. Joshi, Shashank. 2010. "India's Af-Pak Strategy.” RUSI JOURNAL 155(1).

Kaplan, Robert D. 2009. "Centre Stage for the 21st Century: Power Plays in the Indian Ocean.” Foreign Affairs (March/April).

. 2011. MONSOON: The Indian Ocean and the Future of American Power. New York: Random House Trade Paperbacks. . 2012. The Revenge of Geography: What the Map tells us about coming Conflicts and the Battle against Fate. New York: Random House.

Karim, Mohd Aminul. 2014. "Is Nuclear Deterrence Workable at the Brink Time in South Asia and Beyond?" The Korean Journal of Defense Analysis 26(1).

Katzenstein, Peter J. ed. 1996. The Culture of National Security: Norms and Identity in World Politics. New York: Columbia University Press.

News Desk. 2014. "Kayani delayed the Operation: Athar Abbass." The Express Tribune (July 1). Accessed at http://tribune.com.pk/story/729499/ kayani-delayed-the-operation-athar-abbas/.

The International Institute for Strategic Studies(IISS). 2013. The Military Balance 2013. London: Routledge.

Keohane, Robert O. and Joseph S. Nye. 1977. Power and Interdependence. Boston: Little Brown.

Khan, Ahmad. 2015. "Indo-Pak Relations: Views of Pakistan's Political and Religious Parties." Conflict \& Peace Studies 7(1), 105- 127.

Khan, Zulfqar and Rizwana Abbasi. 2013. "Regional-Centric Deterrence: Reassessing its Efficacy for South Asia." The Korean Journal of Defense Analysis 25(4), 489-490.

Khan, Zulfqar. 2000. "The Development of Overt Nuclear Weapon States in 
South Asia: An Investigation of the Divergent Factors that Operated in India and Pakistan from Independence through to 1998." PhD Thesis of Department of Peace Studies, University of Bradford, 103-121. . 2011. "Tactical Nuclear Weapons and Pakistan's Option of OffensiveDeterrence." In Zulfqar Khan. ed. Nuclear Pakistan: Strategic Dimensions. Karachi: Oxford University Press.

. 2013. "South Asian Nuclear Equation: A Perspective." Strategic Studies 33(2), 1-18.

Knorr, Klaus. 1956. “The War Potential of Nations.” Princeton, N.J.: Princeton University Press, 231-239.

Krepon, Michael and Julia Thompson. 2012. "Introduction.” In Michael Krepon and Julia Thompson. eds. Deterrence Stability and Escalation Control in South Asia, Washington: The Stimson Center. . 2004. "The Stability-Instability Paradox, Misperception and Escalation Control in South Asia.” In Michael Krepon, Rodney W. Jones and Ziad Haider. eds. Escalation Control and the Nuclear Option in South Asia, Washington, DC: Stimson Center.

Ladwig III, Walter C. 2007. “A Cold Start for Hot Wars? The Indian Army's New Limited War Doctrine.” International Security 32(3), 157-190.

Latif, S. Amer. 2012. "U.S.-India Military Engagement: Steady as they go.” $A$ Report of the CSIS Wadhwani Chair in U.S.-India Policy Studies, CSIS.

Lehman II, Ronald F. 2014. "Future Technology and Strategic Stability." In Elbridge A. Colby and Michael S. Gerson. eds. Strategic Stability: Contending Interpretations. Carlisle, PA: U.S. Army War College Press.

Lieven, Anatol. 2011. Pakistan: A Hard Country. London: Penguin Books.

Loo, Bernard. 2009. Military Transformation and Strategy. New York: Routledge. Luce, Edward. 2007. In Spite of the Gods: The Strange Rise of Modern India. New York: Doubleday.

Lukes, Steven. 2005. Power: A Radical View. London: Palgrave Macmillan. . "Power and the Battle for Hearts and Minds: On the Bluntness of Soft Power.” In Felix Berenskoetter and M. J. Williams. eds. Power in World Politics, London: Routledge.

Mackinder, Halford J. 1942. Democratic Ideals and Reality: A Study in Politics of Reconstruction. Washington, DC: National Defense University.

Malhotra, Jyoti. 2014. "Modi \& the Two-Nation Theory." The Express Tribune (May 21). Accessed at http://tribune.com.pk/story/710886/modi-thetwo-nation-theory/.

Malik, Mohan. 2008. Energy Flows and Maritime Rivalries in the Indian Ocean Region. Honolulu: Asia-Pacific Center for Security Studies. 
Markey, Daniel S. 2013. No Exit from Pakistan. New Delhi: Cambridge University Press.

Masood, Talat. 2014. "Relating to Modi's India.” The Express Tribune (May 21). Accessed at http://tribune.com.pk/story/710889/relating-to-modisindia/.

Mazza, Michael. 2014. “Can Obama Save His Mighty Pivot to Asia?” The National Interest (April 18). Accessed at http://nationalinterest.org/commentary/can-obama-save-his-mighty-pivotasia-10280 (April 20, 2014).

Mearsheimer, John J. 2001. The Tragedy of Great Power Politics. New York: W. W. Norton.

Global Security. 2015. "Medium Multi-Role Fighter Aircraft (MMRCA/MCRA) Multi-role Fighter." Global Security Organization (April 11). Accessed at http://www.globalsecurity.org/military/world/india/mmrf.htm (April 12, 2015).

Mearsheimer, John J. 1983. Conventional Deterrence. Ithaca, N.Y.: Cornell Univ. Press. . 2001. The Tragedy of Great Power Politics. New York: W. W. Norton \& Co.

. 2004. "Anarchy and the Struggle for Power." In Karen A. Mingst and Jack L. Snyder. eds. Essential Readings in World Politics, New York: W. W. Norton Company, 55 .

. 1982. "Why the Soviets Can’t Win Quickly in Central Europe." International Security 7(1), 3-39.

Mesquita, Bruce Bueno de and William H. Riker. 1983. "An Assessment of the Merits of Selective Nuclear Proliferation." The Journal of Conflict Resolution 26(2), 283-306.

Mistry, Dinshaw. 2011. "Complexity of Deterrence among New Nuclear States: The India-Pakistan Case.” In T. V. Paul, Patrick M. Morgan and James J. Wirtz. eds. Complex Deterrence: Strategy in the Global Age, New Delhi: Cambridge University Press India Pvt. Ltd.

Mitra, Abhijit Iyer. 2014. “India's Nuclear Imposture.” International New York times (May 12).

Morgenthau, Hans J. 1960. Politics among Nations: The Struggle for Power and Peace. New York: Knopf.

Nakamura, David. 2014. "Obama Aims to Reinvigorate Asia Strategy." The Washington Post (April 17). Accessed at http://www.washingtonpost. com/politics/obama-aims-to-reinvigorate-asiastrategy/2014/04/16/ 4a46ed5e-c4bf-11e3-bcec-b71ee10egbc3_print.html (April 20, 2014).

Narang, Vipin. 2013. "Five Myths about India's Nuclear Postures." The 
Washington Quarterly 36(3), 143-157.

Nye, Joseph S. 2011. The Future of Power. New York: Public Affairs.

Onuf, Nicholas Greenwood. 2013. Making Sense, Making Worlds: Constructivism in Social Theory and International Relations. Abingdon: Routledge.

Panda, Ankit. 2015. "India Makes it Official: The 'Mother of All Defense Deals' is Dead." The Diplomat (April 14). Accessed at http://thediplomat.com/ 2015/o4/india-makes-it-official-the-mother-of-all-defense-deals-isdead/ (April 16, 2014).

Nitze, Paul H. 1994. "Is It Time to Junk Our Nukes?” The Washington Post (January 16).

Oelrich, Ivan. 2005. Missions for Nuclear Weapons after the Cold War. Federation of American Scientists, Occasional Paper No. 3.

Perry, William J. 1991. "Desert Storm and Deterrence." Foreign Affairs 70(1), 6682.

Raja, Mudassir. 2014. "Pakistani victims: War on terror toll put at 49,00o." The Express Tribune (March 27).

Samaranayake, Nilanthi. 2014. "The Indian Ocean a Great-Power Danger Zone." The National Interest (May 30).

Schroeder, Paul. 1994. "Historical Reality vs. Neo-Realist Theory.” International Security 19(1), 117-118.

Schweller, Randall L. 1994. "Bandwagoning for Profit: Bringing the Revisionist State Back In.” International Security 19(1), 72-107.

See Luce, Edward. 2007. In Spite of the Gods: The Strange Rise of Modern India. New York: Doubleday.

Singh, Rahul. 2014. "End of the Gandhi Dynasty?" Khaleej Times (April 18). Accessed at http://www.khaleejtimes.com/kt-article-display1.asp?xfile=data/opinion (April 20, 2014).

Smith, David O. 2012. "The U.S. Experience with Tactical Nuclear Weapons: Lessons for South Asia." In Michael Krepon and Julia Thompson. eds. Deterrence Stability and Escalation Control in South Asia, Washington: The Stimson Center.

Snyder, Glenn. 1961. Deterrence and Defense: Toward a Theory of National Security. Princeton, N.J.: Princeton University Press.

Sperling, James. 2010. "National Security Cultures, Technologies of public goods supply and Security Governance.” In Emil J. Kirchner and James Sperling eds., National Security Cultures: Patterns of Global Governance, Abingdon: Routledge.

Spykman, Nicholas J. 1942. America's Strategy in World Politics: The United States and the Balance of Power. New York: Harcourt, Brace. 
Strassler, Robert B. 1976. The Landmark Thucydides: A Comprehensive Guide to the Peloponnesian War. New York: The Free Press.

Stewart-Ingersoll, R. and D. Frazier. 2012. Regional Powers and Security Order: A Theoretical Framework. Abingdon: Routledge.

Tellis, Ashley et. al. 200o. Measuring National Power in the Postindustrial Age: Analyst's Handbook. Santa Monica, CA: RAND. . 2014. Balancing without Containment: An American Strategy for Managing China. Washington, DC: Carnegie Endowment for International Peace.

Walton, C. Dale and Colin S. Gray. 2014. "The Geopolitics of Strategic Stability: Looking Beyond Cold Warriors and Nuclear Weapons.” In Elbridge A. Colby and Michael S. Gerson. eds. Strategic Stability: Contending Interpretations, Carlisle, PA: U.S. Army War College Press.

Waltz, Kenneth N. 1979. Theory of International Politics. New York: McGrawHill. . 1988. “The Origins of War in Neorealist Theory.” Journal of Interdisciplinary History 18(4), 615-628.

Waltz, Stephen M. 2004. "International Relations: One World, Many Theories." In Karen A. Mingst and Jack L. Snyder. ed. Essential Readings in World Politics, New York: W. W. Norton Company, 4-11.

Warner, Rex. 1972. Thucydides: History of the Peloponnesian War. London: Penguin Book.

Wendt, Alexander. 1999. Social Theory of International Politics. Cambridge: Cambridge University Press.

Wohlforth, William C. 1999. "The Stability of a Unipolar World." International Security 24(1), 5-41. 